\title{
Peroral endoscopic pyloromyotomy for gastroparesis: a systematic review and meta-analysis
}

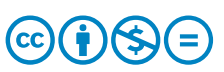

\author{
Authors \\ Karime Lucas Uemura, Dalton Chaves, Wanderley M. Bernardo, Ricardo Sato Uemura, Diogo Turiani Hourneaux de \\ Moura, Eduardo Guimarães Hourneaux de Moura
}

Institution

Gastrointestinal Endoscopy Unit, Hospital das Clínicas da Faculdade de Medicina da Universidade de São Paulo, São Paulo, Brazil

submitted 23.10.2019

accepted after revision 6.1 .2020

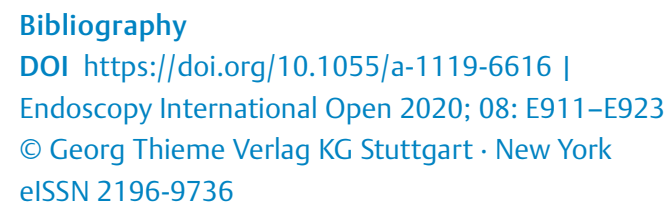

\section{Corresponding author}

Karime Lucas Uemura, Universidade de Sao Paulo Hospital das Clinicas - Gastrointestinal Endoscopy Unit, Av. Dr. Enéas Carvalho de Aguiar, 255 - Cerqueira César Sao Paulo, Sao Paulo 05403-000, Brazil

Fax: +551130697579

karime_lucas@hotmail.com

\section{ABSTRACT}

Background and aim Gastric peroral endoscopic pyloromyotomy (G-POEM) is a new therapeutic option for refractory gastroparesis (GP). A systematic review and meta-analysis was conducted to assess the effectiveness of G-POEM in refractory GP. For the quality of evidence, we used the Grading of Recommendations Assessment, Development and Evaluation (GRADE) criteria.

Methods We performed a literature search using MEDLINE, Embase, Cochrane library, LILACS and the Science citation index for studies related to G-POEM from the inception of its technique through January 2019. We selected studies that analyzed the gastroparesis cardinal symptom index (GCSI) and 4-hour solid-phase gastric emptying scintigraphy (GES) before and after the procedure to verify the efficacy of G-POEM, the main outcome measured. An analysis was performed using RevMan 5.3.

Results Ten studies comprising 281 patients were included in this systematic review. The pooled mean difference in GCSI following the procedure was 1.76 (95\% Cl: [1.43, $\left.2.08], I^{2}=72 \%\right)$. We also performed GCSI subgroup analysis by follow-up duration that showed a pooled mean difference of $1.84\left(95 \% \mathrm{Cl}\right.$ : $\left.[1.57,2.12], \mathrm{I}^{2}=71 \%\right)$. The pooled mean difference in GES after the procedure was 26.28 (95\% Cl: [19.74, 32.83], $\mathrm{I}^{2}=87 \%$ ), corresponding to a significant drop in percentage values of the gastric retention 4-hour scintigraphy.

Conclusion This meta-analysis demonstrates that G-POEM is effective and shows promising outcomes in the clinical response and gastric emptying scintigraphy for gastroparesis. Therefore, it should be considered in the management of refractory gastroparesis.

\section{Introduction}

Gastroparesis (GP) is a difficult-to-treat syndrome in which the diagnosis is suspected because of a constellation of clinical symptoms and is further confirmed based on normal upper endoscopy ruling out any structural obstruction and a 4-hour gastric emptying study proving impaired gastric emptying [1].

Multiple conditions have been associated with gastroparesis, and most etiologies are postsurgically related, diabetic, or idiopathic [2]. Postinfectious, infiltrative and neurological disorders such as amyloidosis and Parkinsonism are also associated [3].
The pathogenesis of delayed gastric emptying is associated with fundus abnormalities, antrum and antroduodenal discoordination, pyloric dysfunction, and abnormal small bowel motility [4]. The pathogenesis of gastroparesis comprises two main components: altered gastric motility and increased pyloric pressure [5].

Gastroparesis treatment involves clinical, surgical and endoscopic interventions.

Surgical and endoscopic interventions may be options for patients with medical refractory gastroparesis [6].

Gastroparesis treatment involves clinical, surgical and endoscopic interventions, and it usually begins with diet modifica- 
tion (low-fat, low-fiber diet) and medications such as antiemetics and prokinetic agents that accelerate gastric emptying and relief symptoms [2,3]. Surgical and endoscopic interventions may be options for patients with medical refractory gastroparesis [6]. Endoscopic treatment options are pyloric botulinum toxin injection, which did not confirm its efficacy in two recent randomized studies [7, 8], dilation, transpyloric stent placement and gastric peroral endoscopic myotomy (G-POEM) [911 ], which is a novel and promising technique that has been introduced recently. From the first use of G-POEM experimentally in 2012 by Kawai et al. and Chaves et al. $[12,13]$ to the first GPOEM performed in humans in 2013 by Khashab et al., followed by Chaves et al. $[14,15]$ this technique has risen in popularity.

Due to its minimally invasive nature, promising outcomes and few adverse events, G-POEM or peroral endoscopic pyloromyotomy (POP) has become a very attractive therapy for refractory gastroparesis with several observational studies and case reports being described. However, to date, no long-term study and no consensus on the efficacy and safety of this technique exists. Thus, we aimed to perform a systematic review data on G-POEM and meta-analysis assessing the efficacy of this procedure.

\section{Methods}

\section{Protocol and registration}

The systematic review was carried out in accordance with the Preferred Reporting Items for Systematic Reviews and MetaAnalyses (PRISMA) guidelines [16] and Meta-Analysis of Observational Studies in Epidemiology (MOOSE) guidelines It was registered in the PROSPERO international database (www.crd. york.ac.uk/prospero/) under the number CRD42019142502.

\section{Eligibility criteria}

a) Type of study: case series, published abstracts and cohort studies.

b) Type of participant: patients older than 18 years undergoing G-POEM with refractory gastroparesis

c) Type of intervention: gastric peroral endoscopic pyloromyotomy

d) Type of outcome measure: the main outcome measure was G-POEM efficacy, defined by improvement in the gastric cardinal symptom index (GCSI) and gastric emptying scintigraphy (GES).

\section{Information sources}

A systematic literature search was performed in MEDLINE, Embase, Cochrane Central Register of Controlled Trials (CENTRAL) and LILACS through January 2019.

\section{Search and study selection}

The following search terms were used in various combinations: gastroparesis, gastric emptying, gastric empty delay, gastric stasis, gastric peroral endoscopic pyloromyotomy (G-POEM), peroral endoscopic pyloromyotomy (POP), endoscopic, endoscopy, surgery, pyloroplasty and pyloromyotomy. Two authors independently searched and extracted the data in a standard- ized manner. Any differences between the reviewers were resolved by consensus.

The articles were screened for the presence of the following inclusion criteria: adult patients with a diagnosis of gastroparesis. Study designs as case reports, cohort and published abstracts were included. Articles in English and Spanish language were included. Experimental studies in animal models and reviews were excluded. Articles were selected for full-text review based on their title and abstract. A manual search through the bibliographies of the retrieved publications was conducted to increase the yield of potentially relevant articles. Additionally, the authors were contacted to obtain unpublished data from their studies, whenever necessary.

In cases where multiple publications were available with an increasing number of patients or a longer follow up for the same group, only data from the most recent article was used for statistical analysis. We only selected studies with GCSI and GES with the mean difference and standard deviation data calculated.

We used a flow diagram to summarize the study selection process.

\section{Data collection process}

Data collection was performed by two reviewers (K.L.U. and D.C.) independently. Disagreements between reviewers were discussed with a third reviewer (W.M.B.), and agreement was reached by consensus. The studies had to analyze GCSI and GES before and after G-POEM, in patients with gastroparesis.

We extracted the following variables: name and year of study; design of study; age; male/female distribution; total number of patients included; number of patients who underwent G-POEM; technical success, clinical success, adverse events, procedure time, myothomy length and length of hospital stay.

\section{Risk of bias and quality of studies}

Publication bias was assessed where necessary by funnel plots and the Egger test of asymmetry. Quality assessment was performed by two authors independently using the Joanna Brigges Index for case series. The quality of evidence was assessed using the Grading of Recommendations Assessment, Development and Evaluation (GRADE) criteria with the GRADEpro Guideline Development Tool software (McMaster University, 2015; Evidence Prime, Inc., Ontario, Canada) [18].

\section{Data synthesis and statistical analysis}

We evaluated the following outcomes in this meta-analysis: (i) gastroparesis cardinal symptom index (GCSI) before and after G-POEM and (ii) gastric emptying scintigraphy at 4 hours (GES) before and after G-POEM. True heterogeneity was presumed and the random effects model was applied in case of persistent high heterogeneity. Heterogeneity was evaluated using Inconsistency $\left(\mathrm{I}^{2}\right)$ statistics and the Cochran $\mathrm{Q}$ test, in which $P<0.05$ for the Cochran $\mathrm{Q}$ test indicated the presence of heterogeneity. The $\mathrm{I}^{2}$ values $>50 \%$ were consistent with significant heterogeneity. Tests of significance comparing pre- and post-procedure outcomes of interest were performed using two sample $t$ tests 
or analysis of variance (ANOVA) for continuous variables and chi-square or Fisher exact test for categorical variables. All statistical analyses were conducted using RevMan software (Review Manager Version 5.3; The Nordic Cochrane Centre, Copenhagen, Denmark) and Comprehensive Meta-Analysis (CMA) software (version 3.0; Biostat, Englewood, New Jersey, United States).

\section{Results}

\section{Study selection}

The search strategy identified 7,513 publications, of which 419 were removed as duplicate publications and 7,010 were excluded based on title and abstract review. A total of 84 articles underwent full-text review, of which 76 studies were further excluded for various reasons: five studies were review articles, three were animal studies, one study had an overlap population, one study was published in two different journals, one was not related to G-POEM, and one study presented different GCSI data. We only selected studies with calculated standard deviation values (SD); thus, we had to exclude 62 additional studies missing GCSI and/or GES data. Therefore, 10 studies were included in this meta-analysis. An adapted PRISMA flow diagram illustrates the study selection process ( $\triangleright$ Fig. $\mathbf{1}$ ).

\section{Study characteristics and quality assessment}

Among the 10 studies included in this meta-analysis, four were prospective [19-22], including two published abstracts [20, 21], and 6 were retrospective [1,23-27], including also another abstract [27], which we chose instead of the published article from the same group, because it is more recent and has a larger number of patients [28]. In total, 281 patients were included in this meta-analysis. We excluded 3 patients from the Xue et al. [26] study in which the pyloric ring was not identified during routine G-POEM. A summary of the characteristics of the included studies is shown in $>$ Table 1. Landrenau et al. [1] were the only authors who compared G-POEM to laparoscopic pyloroplasty; thus, we did not analyze the laparoscopic data. Mekaroonkamol et al. [23] aimed to identify predictive factors of the clinical response after G-POEM and compared outcomes between diabetes gastroparesis and non-diabetes gastroparesis (NDG). Xue et al. [26] performed fluoroscopy-guided G-POEM to direct the orientation of the submucosal tunnel, to facilitate the location of the pyloric muscle ring and shorten the procedure time, while Malik et al. and Jacques et al. [22, 24] used EndoFLIP to determine whether pyloric sphincter characteristics existed that could predict a successful procedure. The remaining authors performed routine G-POEM.

Using the Joanna Briggs Institute (JBI) Critical Appraisal Checklist for Case Series quality assessment, all 10 studies did not clearly report the demographics of the participants. Five studies did not report clear information about the participants [20-23, 27] and two were unclear [25, 26] The Hustak et al. [20] study was the only one that did not report clear information about the site/clinic demographic information. Quality assessment is shown in $>$ Table 2 .

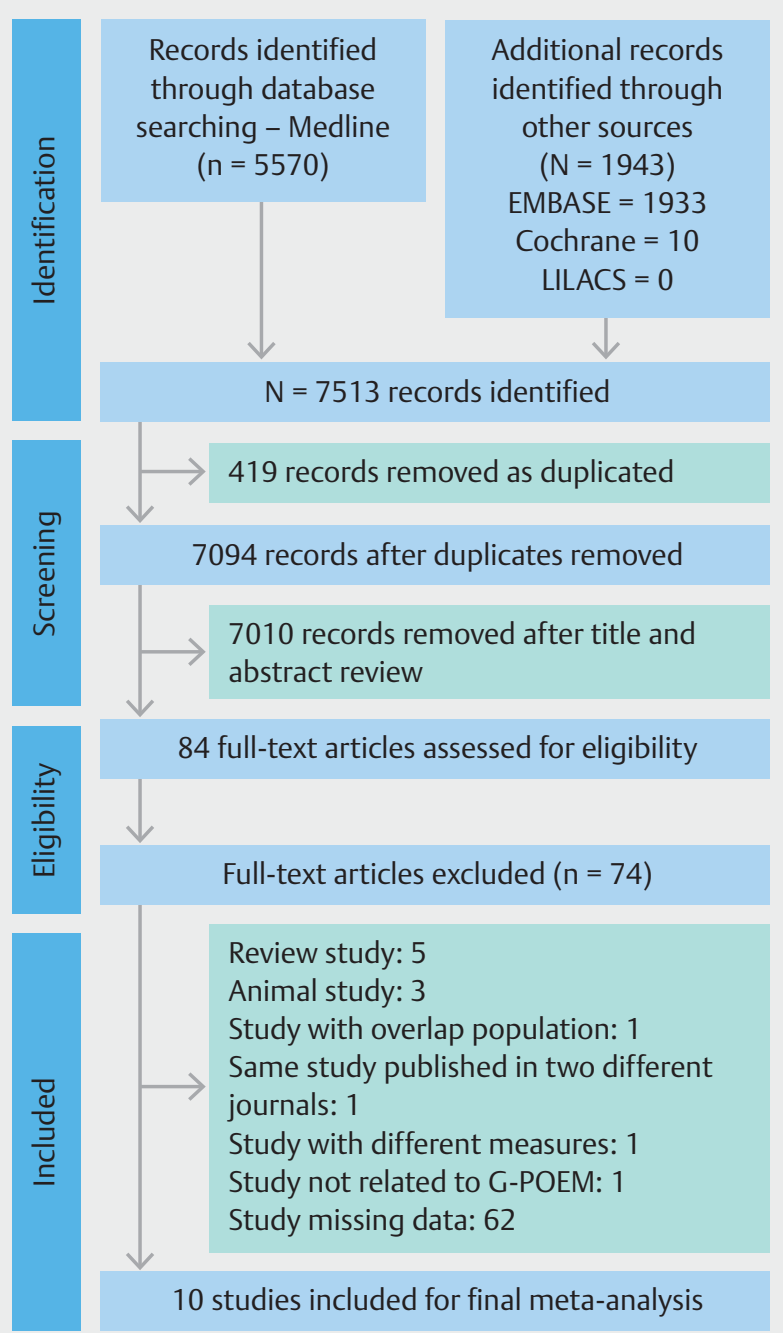

- Fig. 1 Search strategy and study selection flowchart.

\section{Meta-analysis}

\section{GCSI}

Ten studies were included with 281 patients to evaluate the general GCSI before and after the procedure, and the longest follow-up values from each study were included in this analysis. The pooled mean difference in GCSI following the procedure with a $95 \%$ confidence interval was $1.76[1.43,2.08]$ by the Cochran $Q$ test $\left(P=0.0002, I^{2}=72 \%\right)$ ( Fig. 2 ). All the studies reported a decrease in the values of GCSI after G-POEM, and we used the longest follow up to calculate this. However, we found one study with publication bias, from Malik et al. [24], which was presented as an outlier during the general analysis. The $\mathrm{I}^{2}$ values dropped from $72 \%$ to $50 \%$ after excluding this study as shown in > Fig. 3 and > Fig. 4. There were different baseline GCSI values among the included studies, with different disease severities but although statistically significant $(P<0.0000001)$, these differences are already expected in this type of meta-analysis. 


\section{总产}

\begin{tabular}{|c|c|c|}
\hline 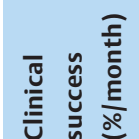 & $\frac{s}{z}$ & 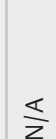 \\
\hline
\end{tabular}

$m$
$m$
$\stackrel{\circ}{E}$
$\stackrel{n}{0}$
$\stackrel{n}{n}$

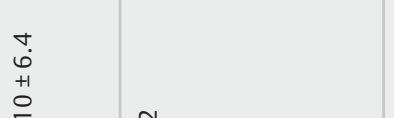

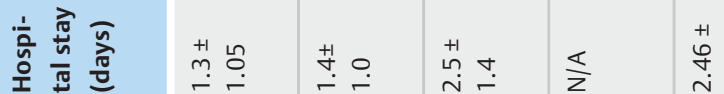

\begin{tabular}{|c|c|c|c|}
\hline$\stackrel{\infty}{\stackrel{\infty}{2}}$ & $\stackrel{\Xi}{\sim}$ & 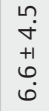 & $m$ \\
\hline 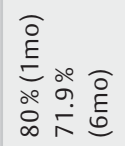 & 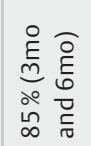 & $\stackrel{\stackrel{\circ}{m}}{\stackrel{1}{r}}$ & $\begin{array}{l}\stackrel{\partial}{E} \\
\stackrel{0}{\circ} \\
\stackrel{\circ}{\curvearrowright}\end{array}$ \\
\hline
\end{tabular}

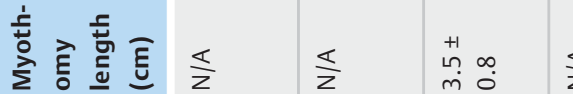

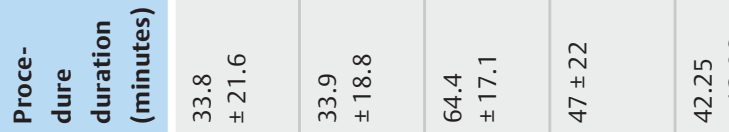

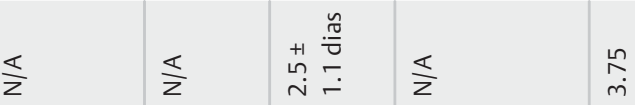

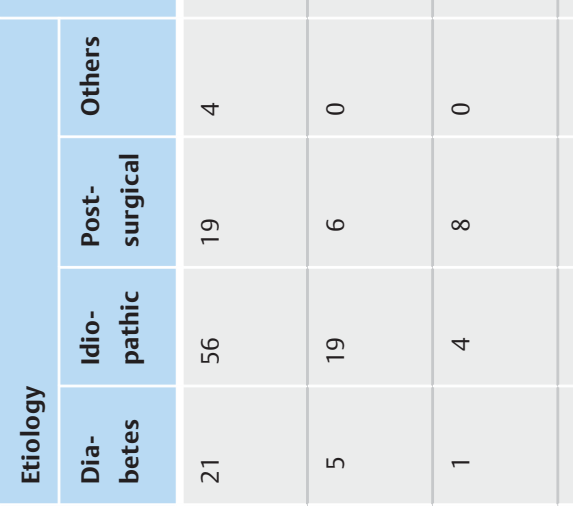

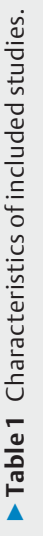

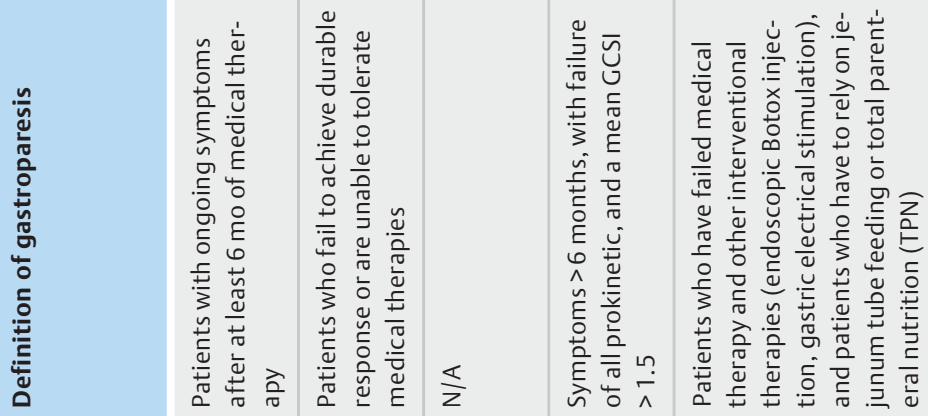

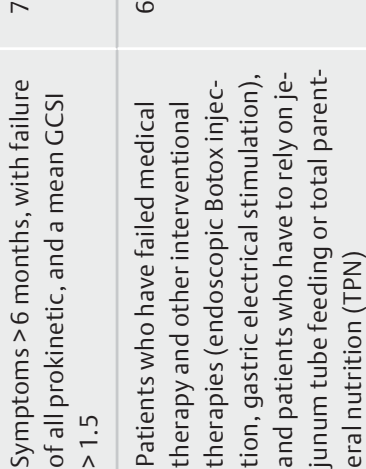

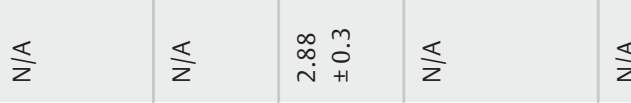

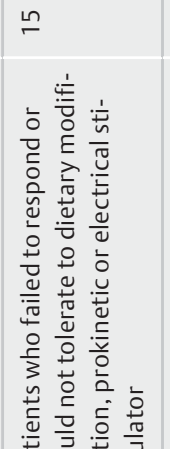

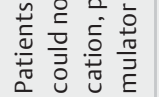

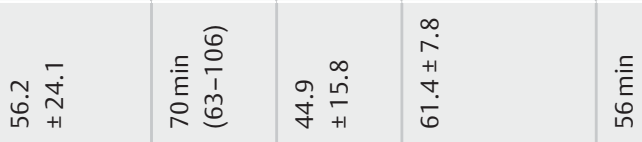

$\frac{\pi}{2}$

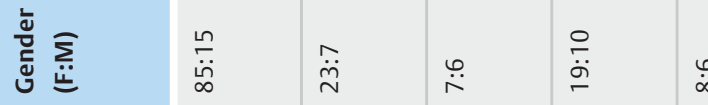

\begin{tabular}{|c|c|c|c|c|}
\hline 芩 & 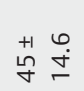 & $-\stackrel{\stackrel{n}{m}}{\frac{n}{f}}$ & 荌管 & 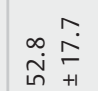 \\
\hline 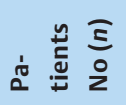 & $\stackrel{\circ}{-}$ & ஜे & $\stackrel{m}{\sim}$ & $\stackrel{\text { N }}{ }$ \\
\hline
\end{tabular}

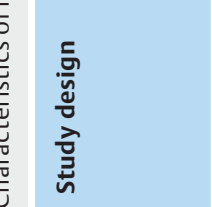

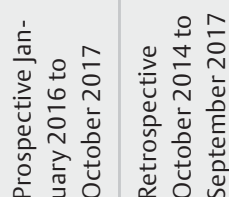

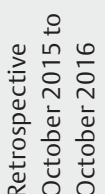

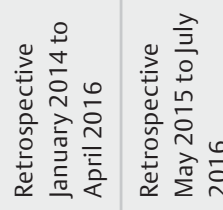

$\stackrel{n}{m}$

\begin{tabular}{l|l|l}
0 & - \\
0 & 0
\end{tabular}

\begin{tabular}{|c|c|c|c|c|}
\hline i & 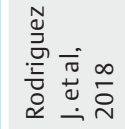 & 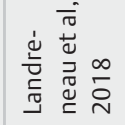 & 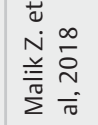 & 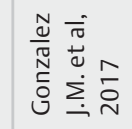 \\
\hline
\end{tabular}

\begin{tabular}{|c|c|c|c|c|}
\hline$=\frac{n}{r} \frac{n}{+1}$ & $\frac{\mathbb{z}}{z}$ & $\frac{\sigma}{g} \stackrel{m}{\emptyset}$ & 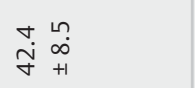 & $\frac{\pi}{z}$ \\
\hline & r & N & $\sigma$ & 尺 \\
\hline 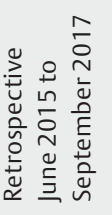 & 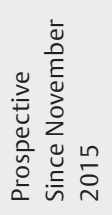 & 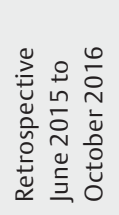 & 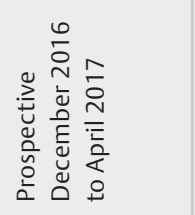 & 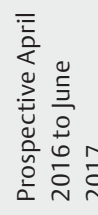 \\
\hline 还 & 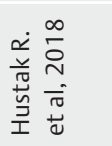 & 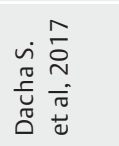 & 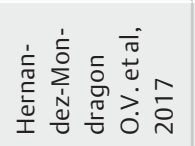 & 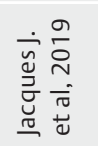 \\
\hline
\end{tabular}


- Table 2 Quality assessment studies for case series.

\begin{tabular}{|c|c|c|c|c|c|c|c|c|c|c|}
\hline $\begin{array}{l}\text { Joanna Briggs } \\
\text { Institute - JBI }\end{array}$ & $\begin{array}{l}\text { Rodri- } \\
\text { guez et } \\
\text { al, } 2018\end{array}$ & $\begin{array}{l}\text { Landre- } \\
\text { neau et } \\
\text { al, } 2018\end{array}$ & $\begin{array}{l}\text { Malik et } \\
\text { al, } 2018\end{array}$ & $\begin{array}{l}\text { Gonzalez } \\
\text { et al, } \\
2017\end{array}$ & $\begin{array}{l}\text { Xue et } \\
\text { al, } 2017\end{array}$ & $\begin{array}{l}\text { Mekar- } \\
\text { oonka- } \\
\text { mol et } \\
\text { al, } 2019\end{array}$ & $\begin{array}{l}\text { Hustak } \\
\text { et al, } \\
2018\end{array}$ & $\begin{array}{l}\text { Dacha et } \\
\text { al, } 2017\end{array}$ & $\begin{array}{l}\text { Jacques } \\
\text { J. et al, } \\
2019\end{array}$ & $\begin{array}{l}\text { Hernandez- } \\
\text { Mondragon } \\
\text { O.v. et al, } \\
2017\end{array}$ \\
\hline $\begin{array}{l}\text { Were there clear } \\
\text { criteria for inclusion } \\
\text { in the case series? }\end{array}$ & Y & Y & Y & Y & Y & Y & Y & Y & Y & Y \\
\hline $\begin{array}{l}\text { Was the condition } \\
\text { measured in a stand- } \\
\text { ard, reliable way for all } \\
\text { participants included } \\
\text { inthe case series? }\end{array}$ & Y & Y & Y & Y & Y & Y & Y & $\mathrm{Y}$ & Y & Y \\
\hline $\begin{array}{l}\text { Were valid methods } \\
\text { used for identification } \\
\text { of the condition for all } \\
\text { participants included } \\
\text { in the case series? }\end{array}$ & Y & Y & Y & Y & Y & Y & Y & Y & Y & Y \\
\hline $\begin{array}{l}\text { Did the case series } \\
\text { have consecutive in- } \\
\text { clusion of partici- } \\
\text { pants? }\end{array}$ & Y & Y & Y & Y & Y & Y & Y & Y & Y & Y \\
\hline $\begin{array}{l}\text { Did the case series } \\
\text { have complete inclu- } \\
\text { sion of participants? }\end{array}$ & Y & Y & Y & Y & Y & Y & Y & Y & Y & Y \\
\hline $\begin{array}{l}\text { Was there clear re- } \\
\text { porting of the demo- } \\
\text { graphics of the parti- } \\
\text { cipants in the study? }\end{array}$ & $\mathrm{N}$ & $\mathrm{N}$ & N & $\mathrm{N}$ & N & N & N & N & N & N \\
\hline $\begin{array}{l}\text { Was there clear re- } \\
\text { porting of clinical in- } \\
\text { formation of the par- } \\
\text { ticipants? }\end{array}$ & Y & Y & Y & U & U & N & N & N & N & $N$ \\
\hline $\begin{array}{l}\text { Were the outcomes or } \\
\text { follow up results of } \\
\text { cases clearly report- } \\
\text { ed? }\end{array}$ & Y & Y & Y & Y & Y & Y & Y & Y & Y & Y \\
\hline $\begin{array}{l}\text { Was there clear re- } \\
\text { porting of the pre- } \\
\text { senting site(s)/clinic } \\
\text { (s) demographic in- } \\
\text { formation? }\end{array}$ & Y & Y & Y & Y & Y & Y & N & Y & Y & Y \\
\hline $\begin{array}{l}\text { Was statistical analy- } \\
\text { sis appropriate? }\end{array}$ & Y & Y & Y & Y & Y & Y & Y & Y & Y & Y \\
\hline Overall appraisal: & Include & Include & Include & Include & Include & Include & Include & Include & Include & Include \\
\hline
\end{tabular}

\section{GCSI subgroup}

We also analyzed GCSI 3, 6, 12 and 18 months following the procedure. The Xue et al. [20] study was not included in this subgroup analysis because the results were described at the 1month follow up. Gonzalez et al. [25], Hustak et al. [20], Landreneau et al. [1], Malik et al. [24], Jacques et al. [22], Hernandez Mondragon et al. [21] and Rodriguez et al.[19] reported the mean difference between GCSI before and after 3 months of G-POEM with a $95 \%$ confidence interval as 1.76 [1.26-2.25] by the Cochran $\mathrm{Q}$ test $\left(P<0.0001, I^{2}=81 \%\right)$. Although the hetero- geneity was high, all the studies showed improvement in the GCSI score after the procedure. Four studies completed 6 months of follow up [20,27], two studies completed 12 months $[20,27]$, and one study 18 months [23] following the procedure. These studies showed a decrease in the values of $\mathrm{GSCl}$ after G-POEM, and the overall mean difference for the GCSI subgroup was 1.84 [1.57-2.12] with a $95 \%$ confidence interval by the Cochrane $Q$ test $\left(P<0.0001 ; I^{2}=71 \%\right)$ ( Fig. 5). Hustak et al. [20] reported that one woman completed 24 months of follow up, although their complete data are missing. 


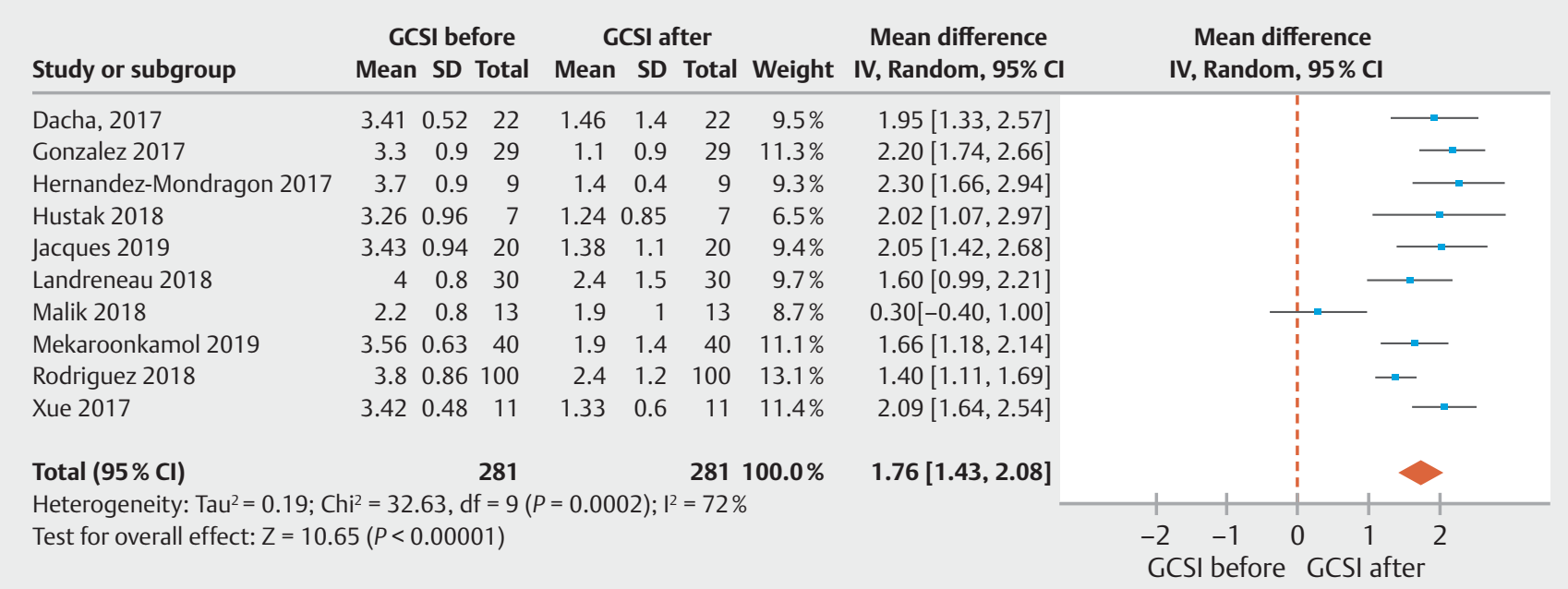

Fig. 2 Forest plot to compare GCSI before and after G-POEM.

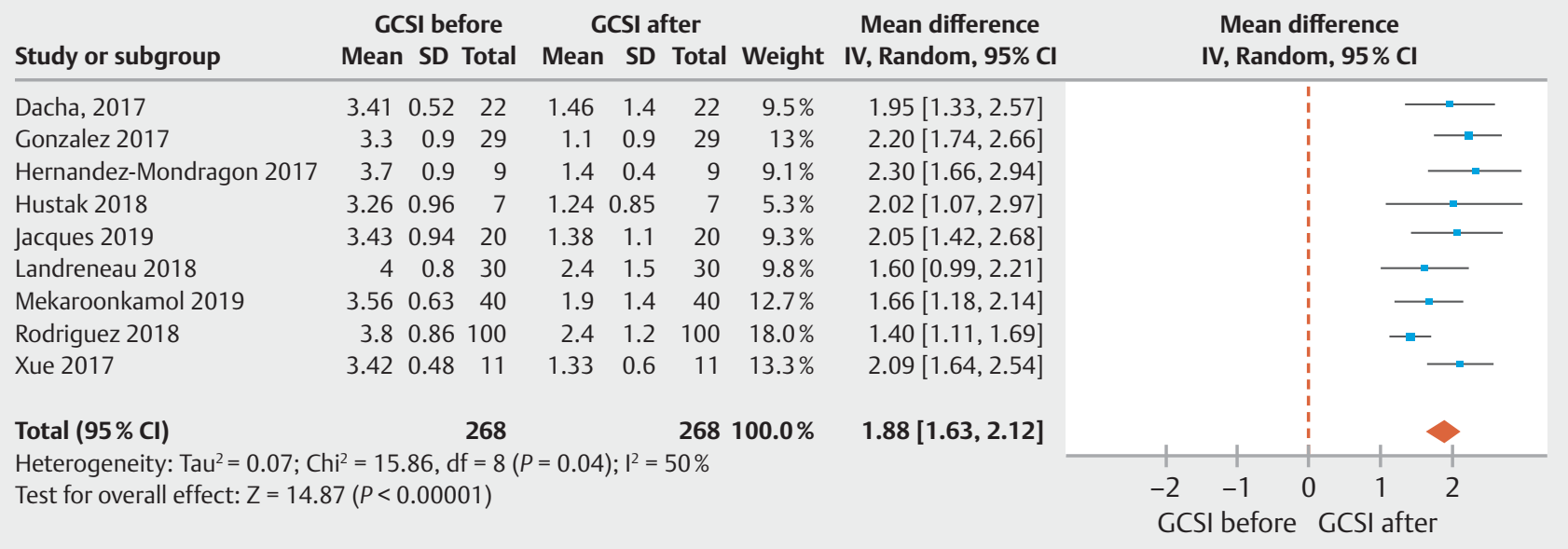

Fig. 3 Forest plot to compare GCSI before and after G-POEM without the outlier.
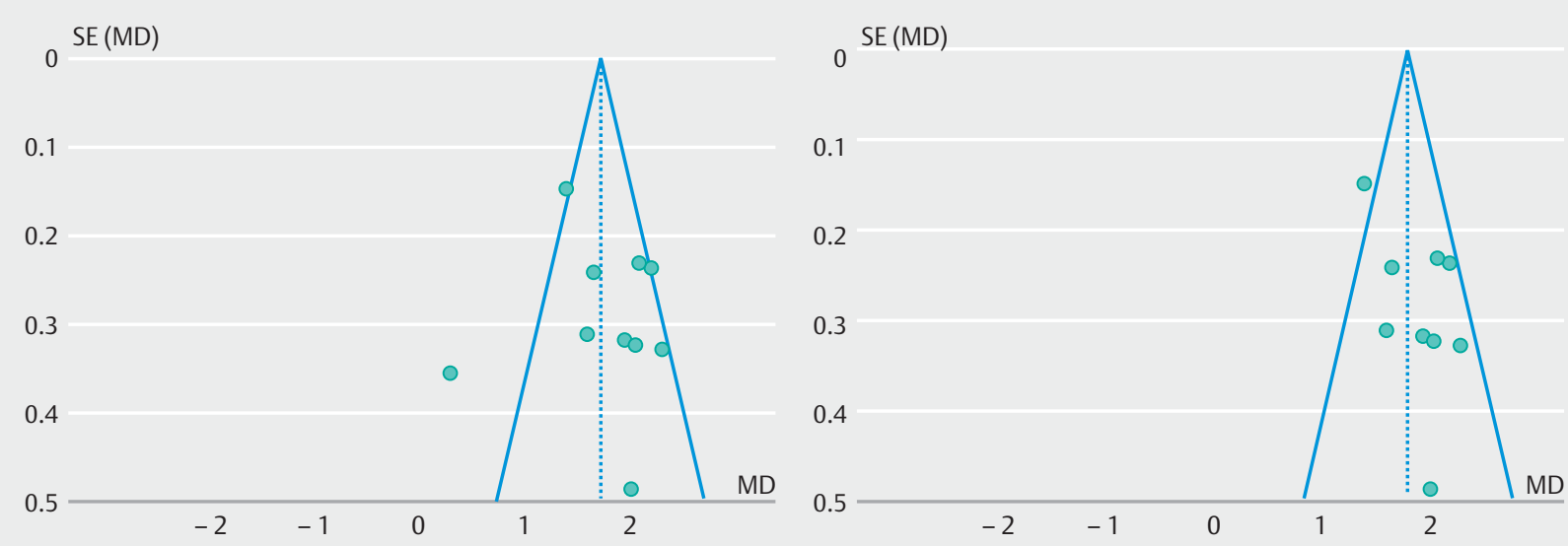

Fig. 4 Funnel plot to show the outlier study in GCSI analysis. 


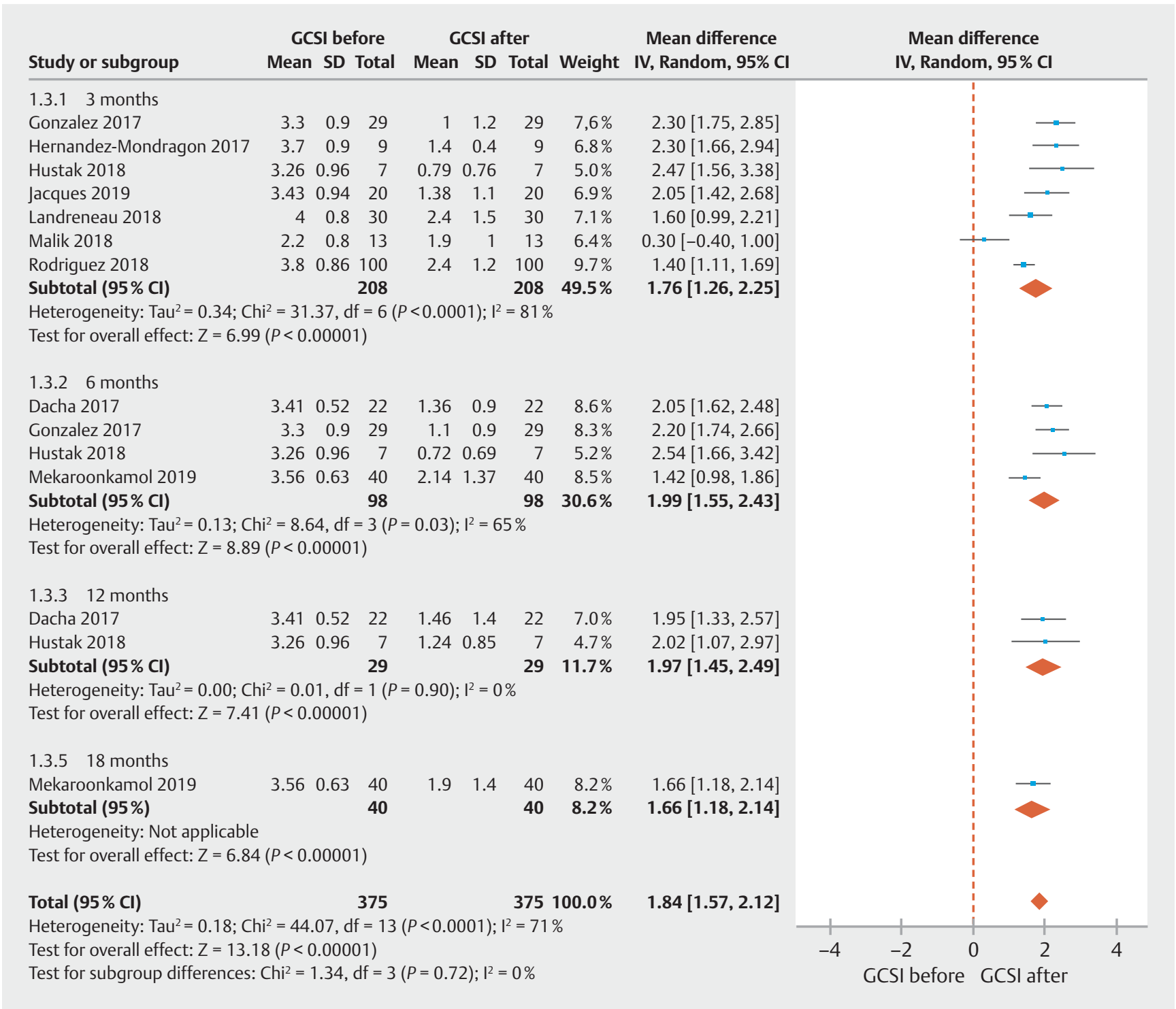

- Fig. 5 Forest plot to compare GCSI subgroup before and after G-POEM.

\section{GES}

For GES, all ten studies were included with 252 patients. The patients had preoperative GES, and the GES control was performed 2 to 3 months after the procedure. There was a significant decrease in the percentage of the gastric retention 4-hour scintigraphy after the procedure, and the mean difference was 26.28 [19.74-32.83] with the $95 \%$ confidence interval by the Cochrane $Q$ test $\left(P<0.00001 ; I^{2}=87 \%\right)$. Therefore, the heterogeneity was as high as that encountered in the GSCl results ( Fig. 6).

According to the GRADE criteria for the quality of evidence, the evidence for our GCSI outcomes generated low certainty and for the GCSI subgroup and GES, very low certainty, as shown in $>$ Table 3 .

\section{Discussion}

\section{Summary of evidence}

To our knowledge, this is the first systematic review and metaanalysis including published papers and abstracts studies that compared GCSI and GES values pre- and post G-POEM in cases of refractory gastroparesis, based on data with mean difference and calculated standard deviation data of each study. Our strict methodology, which included critical appraisal of biases, quality of evidence assessment, and a report prepared in accordance with the PRISMA guidelines [16], underscores the strength of our findings. G-POEM seems to be a very good option in the arsenal treatment for refractory gastroparesis, with a rate of $100 \%$ technical success and $71 \%$ clinical success.

First-line therapies on the management of GP are diet modification (low fat, low fiber diet) and medications such as antiemetics and prokinetic agents that accelerate gastric emptying 


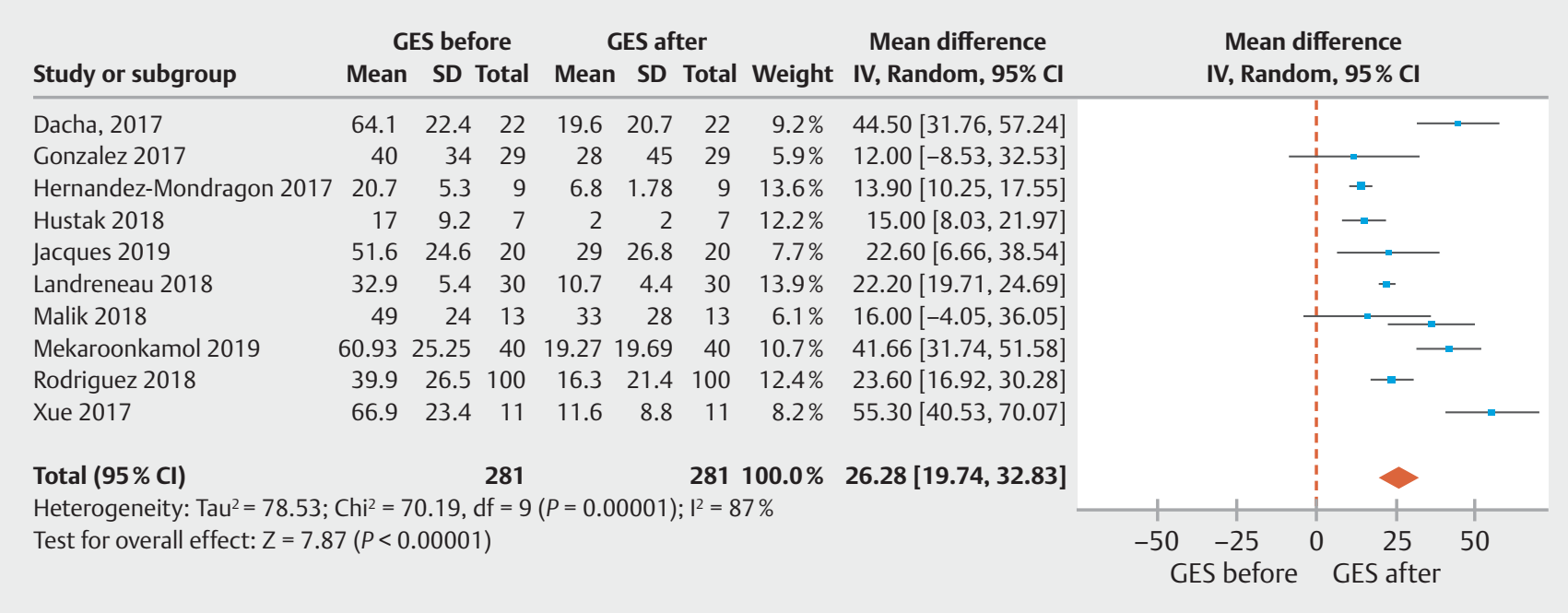

Fig. 6 Forest plot to compare GES before and after G-POEM.

- Table 3 Quality (certainty) of evidence of the studies selected, as determined by the GRADE criteria.

\begin{tabular}{|c|c|c|c|c|c|c|c|c|c|c|c|c|}
\hline \multicolumn{7}{|c|}{ Certainty assessment } & \multicolumn{2}{|c|}{ No. of patients } & \multicolumn{2}{|l|}{ Effect } & \multirow[t]{2}{*}{ Certainty } & \multirow{2}{*}{$\begin{array}{l}\text { Impor- } \\
\text { tance }\end{array}$} \\
\hline $\begin{array}{l}\text { No. of } \\
\text { stud- } \\
\text { ies }\end{array}$ & $\begin{array}{l}\text { Study } \\
\text { design }\end{array}$ & $\begin{array}{l}\text { Risk } \\
\text { of bias }\end{array}$ & $\begin{array}{l}\text { Incon- } \\
\text { sisten- } \\
\text { cy }\end{array}$ & $\begin{array}{l}\text { Indir- } \\
\text { ect- } \\
\text { ness }\end{array}$ & $\begin{array}{l}\text { Impre- } \\
\text { cision }\end{array}$ & $\begin{array}{l}\text { Other } \\
\text { consid- } \\
\text { erations }\end{array}$ & $\begin{array}{l}\text { GCSI } \\
\text { and GES } \\
\text { before } \\
\text { G-POEM }\end{array}$ & $\begin{array}{l}\text { After G- } \\
\text { POEM }\end{array}$ & $\begin{array}{l}\text { Rela- } \\
\text { tive } \\
\text { (95\% } \\
\text { Cl) }\end{array}$ & $\begin{array}{l}\text { Absolute } \\
(95 \% \mathrm{Cl})\end{array}$ & & \\
\hline \multicolumn{13}{|c|}{ GCSI (follow up: range 3 months to 18 months; Scale from: 0 to 5 ) } \\
\hline 10 & $\begin{array}{l}\text { Observa- } \\
\text { tional } \\
\text { studies }\end{array}$ & $\begin{array}{l}\text { Not } \\
\text { ser- } \\
\text { ious }\end{array}$ & $\begin{array}{l}\text { Not } \\
\text { ser- } \\
\text { ious }\end{array}$ & $\begin{array}{l}\text { Not } \\
\text { ser- } \\
\text { ious }\end{array}$ & $\begin{array}{l}\text { Not } \\
\text { ser- } \\
\text { ious }\end{array}$ & None & 281 & 281 & - & $\begin{array}{l}\text { MD } 1.62 \text { higher } \\
\text { ( } 1.45 \text { higher to } \\
1.8 \text { higher) }\end{array}$ & $\begin{array}{l}\oplus \oplus \circ \bigcirc \\
\text { Low }\end{array}$ & $\begin{array}{l}\text { Impor- } \\
\text { tant }\end{array}$ \\
\hline \multicolumn{13}{|l|}{ GES } \\
\hline 10 & $\begin{array}{l}\text { Observa- } \\
\text { tional } \\
\text { studies }\end{array}$ & $\begin{array}{l}\text { Not } \\
\text { ser- } \\
\text { ious }\end{array}$ & $\begin{array}{l}\text { Very } \\
\text { ser- } \\
\text { ious }^{1}\end{array}$ & $\begin{array}{l}\text { Not } \\
\text { ser- } \\
\text { ious }\end{array}$ & $\begin{array}{l}\text { Not } \\
\text { ser- } \\
\text { ious }\end{array}$ & None & 281 & 281 & - & $\begin{array}{l}\text { MD } 26.62 \text { higher } \\
\text { (19.7 higher to } \\
33.55 \text { higher) }\end{array}$ & $\begin{array}{l}\oplus \circ \circ \bigcirc \\
\text { Very low }\end{array}$ & $\begin{array}{l}\text { Impor- } \\
\text { tant }\end{array}$ \\
\hline \multicolumn{13}{|c|}{ GCSI subgroup } \\
\hline 9 & $\begin{array}{l}\text { Observa- } \\
\text { tional } \\
\text { studies }\end{array}$ & $\begin{array}{l}\text { Not } \\
\text { ser- } \\
\text { ious }\end{array}$ & $\begin{array}{l}\text { Ser- } \\
\text { ious }^{2}\end{array}$ & $\begin{array}{l}\text { Not } \\
\text { ser- } \\
\text { ious }\end{array}$ & $\begin{array}{l}\text { Not } \\
\text { ser- } \\
\text { ious }\end{array}$ & $\begin{array}{l}\text { Publica- } \\
\text { tion bias } \\
\text { strongly } \\
\text { suspected }\end{array}$ & 375 & 375 & - & $\begin{array}{l}\text { MD } 1.79 \text { higher } \\
\text { ( } 1.49 \text { higher to } \\
2.09 \text { higher) }\end{array}$ & $\begin{array}{l}\oplus \circ \circ \bigcirc \\
\text { Very low }\end{array}$ & $\begin{array}{l}\text { Impor- } \\
\text { tant }\end{array}$ \\
\hline \multicolumn{13}{|c|}{$\begin{array}{l}\mathrm{Cl} \text {, confidence interval; MD, mean difference; GCSI, gastroparesis cardinal symptom index; GES, gastric emptying scintigraphy; G-POEM, gastric peroral endoscopic py- } \\
\text { loromyotomy. } \\
{ }^{1} \text { Heterogeneity above } 75 \% \\
{ }^{2} \text { Heterogeneity between } 50 \% \text { and } 75 \%\end{array}$} \\
\hline
\end{tabular}

and relief symptoms. Metoclopramide and domperidone, a D2 dopamine receptor antagonist, are the most widely used drugs, but only metoclopramide is currently approved by the Food and Drug Administration (FDA) in the United States. This treatment has limited efficacy and carries a black-box warning for tardive dyskinesia [29, 30]. This makes management more challenging, and patients frequently present with severe symptoms due to either progression of the disease or medications losing efficacy over time, turning the disease refractory to medical treatment [31].
Surgery may be next step for treatment of refractory gastroparesis. The surgery options include implantation of gastric stimulators, Roux-en-Y gastric bypass, subtotal gastrectomy, gastrostomy, jejunostomy and pyloric interventions such as pyloromyotomy and pyloroplasty [6,32]. However, gastric electrical stimulation has often been considered first line in the treatment of medically refractory patients with the best level of evidence [33].

Gastric electrical stimulation is a surgically implanted treatment option to treat gastroparesis resistant to medical therapy 
Table4 Excluded studies.

\begin{tabular}{|l|l|l|l|}
\hline Study & Study Design & Patients No (n) & Reason for exclusion \\
\hline Jiaxin Xu et al, 2018 & Retrospective Single center - China & 16 & GES 4h missing data \\
\hline Kahaleh M. Et al, 2018 & Case series Multicenter - USA/France & 33 & Missing SD data \\
\hline Khashab M. et al, 2017 & $\begin{array}{l}\text { Retrospective Multicenter - USA/Asia/South } \\
\text { America }\end{array}$ & 30 & $\begin{array}{l}\text { GCSI missing data / Invalidated symptoms } \\
\text { questionnaire }\end{array}$ \\
\hline Allemang M.T. et al, 2017 & Retrospective Single center - USA & 57 & GES missing data \\
\hline Shlomovitz E. et al, 2015 & Retrospective Single center - USA & 7 & $\begin{array}{l}\text { GCSI missing data / Invalidated symptoms } \\
\text { questionnaire }\end{array}$ \\
\hline
\end{tabular}

[32]. This therapy seems to significantly decrease gastrointestinal symptoms and improve the quality of life in patients with severe gastroparesis [34]. However, complications occur in 5\% to $20 \%$ of patients, such as infections, migration and erosion of the stimulating device, gastric perforation, abdominal pain, dislodgment, stomach wall perforation and intestinal obstruction $[33,35]$. To minimize complications, simultaneous intraoperative endoscopy is now routinely performed to permit immediate detection of gastric wall perforation, and then electrode repositioning can occur at the same operative moment [34]. Although a role likely exists for gastric stimulation in the treatment of refractory gastroparesis symptoms, there are a substantial number of patients who cannot access the technology or for whom it does not work [36].

Pyloric dysfunction may play a role in a subset of patients with gastroparesis; thus, pyloric interventions have risen in popularity. Surgical techniques have aimed to disrupt pyloric barrier function and facilitate gastric emptying. Botox injections, endoscopic balloon dilatation, pyloroplasty, pyloromyotomy and transpyloric stent placement have all been employed with varying successes [9-11]. Use of botulinum toxin is controversial and has not shown a benefit in randomized trials, although it improves gastric emptying in patients with gastroparesis, this benefit was not superior to placebo and it is no longer recommended by American College of Gastroenterology [7, 8, 37]

Jones et al performed a review of surgical therapy for gastroparesis and demonstrated that gastrectomy, gastric stimulation, gastrostomy, and jejunostomy are not benign interventions and that the true efficacy of these procedures is not known [38]

Laparoscopic pyloroplasty can accelerate gastric emptying and improve symptoms in select patients with a suspicion of pyloric dysfunction and refractory symptoms [11]. Hibbard et al. and Toro et al. described a similar retrospective study of their experience with this procedure in 28 and 50 patients, respectively, reporting symptomatic improvement in $83 \%$ and $82 \%$, respectively $[36,39]$. Therefore, few complications are described, such as leaks, wound infections and hospital readmission, to control refractory symptoms or for reoperation $[1,11]$.

Although there seems to be a role for gastric stimulation and laparoscopic pyloroplasty, in the treatment of refractory gastroparesis symptoms, they are invasive techniques with a high rate of complications and recurrence of patient symptoms, making physicians aim for a novel and less invasive procedure.

Increasingly more studies have been published performing G-POEM for refractory gastroparesis, since it was first performed in 2013. However, no randomized or comparative study exists regarding its safety and efficacy Nevertheless, all the published studies have reported high rates of clinical success.

From our search, we found 84 papers on G-POEM worldwide, indicating this technique has been performed increasingly. We could only include 10 studies in this meta-analysis because the studies had to contain all the data for GCSI and GES before and after the procedure with calculated SD values. Many other studies were found, and all of them were related to safety and improvement using either the GES or GCSI scores [31,40-44] Khashab et al., for example, unfortunately used an invalidated gastroparesis symptom questionnaire. Thus, the study could not enter this meta-analysis, however, it was the first multicenter study of five centers and included 30 patients, with very consistent results showing a $100 \%$ procedural success, an $86 \%$ clinical response and a $7 \%$ complication rate [31]. Shlomovitz et al. [42] reported the first case series in 2015 but unfortunately, there were missing data and we also couldn't include this study in our analysis. Other excluded studies are shown in $>$ Table 4.

The only study found in the literature that compares GPOEM with laparoscopic pyloroplasty (LP) was described by Landreneau J. et al. and was related to significant improvement in the GES and GCSI scores, with no differences in these outcome measures between the interventions. However, G-POEM appears to be superior to LP because it shows less perioperative morbidity, including the operative time, estimated blood loss, and length of hospital day [1].

The studies included in this meta-analysis demonstrate significant symptom improvement, yielding a pooled mean difference in clinical success of $0.71\left(95 \% \mathrm{Cl},[0.63,0.79] \mathrm{I}^{2}=45 \%\right)$ ( Fig. 7). However, the follow-up duration was quite heterogeneous across all studies, varying from 1 to 24 months; therefore, we calculated the clinical success rate with the longest follow-up data available provided in seven studies [20-25,27]. We included one published abstract in this meta-analysis, from Hustak et al. [20], that has the longest follow-up period, where one woman from a total of seven patients included had finished the 24-month follow up and maintained an excellent outcome (mean GCSI: 0.77). However, unfortunately, we could not in- 


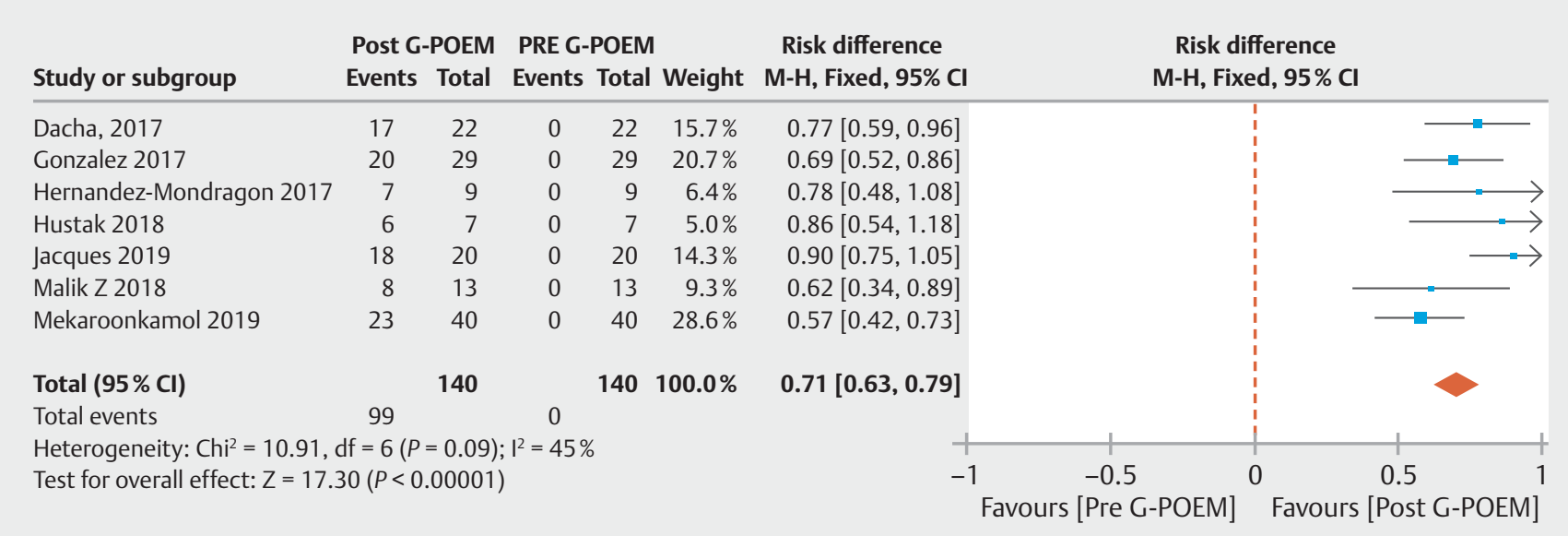

Fig. 7 Forest plot to demonstrate clinical success.

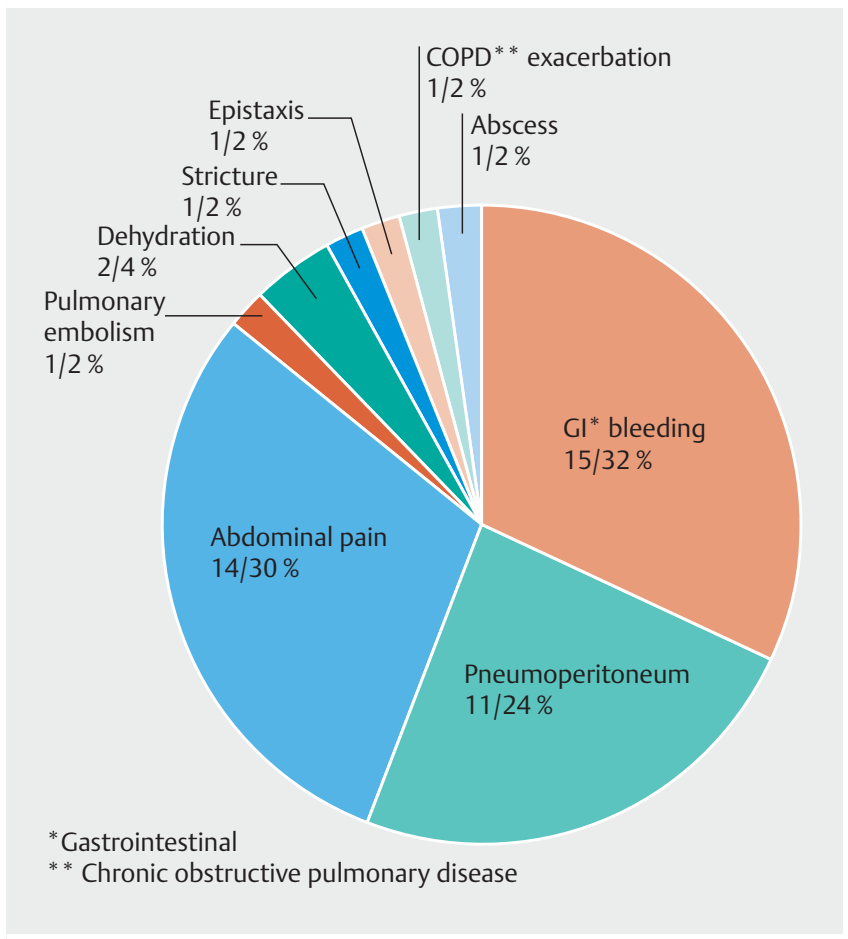

Fig. 8 Adverse events.

clude this last result in our analysis because it did not have the calculated SD values. All the studies but one showed a significant reduction in the total GCSI after G-POEM [1, 19-23, 2527]. This lack of significant change in the GSCI values might have been due to its lower GCSI values before the procedure and it may be the reason why Malik et al. [24] is represented as an outlier. However, in this study, it did not seem to have a relevant decrease in GCSI values, most of the patients reported improvement. Another interesting point was that patients with a lower starting $\mathrm{GSCl}$ and fewer severe symptoms showed a better response, suggesting that pyloromyotomy should be performed earlier in the disease course rather than in patients who are refractory to other treatments to reach better results
[24]. Only a few studies reported GCSI subscales [1,22-24]. Jacques et al. and Landreneau et al. [1,22] showed significant improvement in all GCSI subscales (nausea/vomiting, early satiety and bloating) at 3 months while Mekaroonkamol et al. [23] reported sustained improvement only in the 12-month nausea/ vomiting subscale. Malik et al. [24] showed no significant difference between pre and post-GCSI scores.

The endoscopic functional luminal imaging probe (EndoFLIP) is a system that can assess pyloric dysfunction in patients with gastroparesis by measuring the length, pressure, cross sectional area (CSA), and distensibility of the pylorus. Malik et al. [24] showed that the pyloric diameter and CSA were inversely correlated with the symptom severity, such as early satiety and postprandial fullness. However, when they used EndoFlip measurements pre- and post-G-POEM, only one measurement showed a significant difference when comparing patients who clinically improved with those who did not [24]. The same group showed that, while the average pyloric pressure decreases, the cross-sectional area and pyloric diameter increase significantly after G-POEM. Jacques et al. [22], in a prospective trial, showed that all the subjects benefited from the EndoFLIP analysis of pyloric function before G-POEM. EndoFLIP can also be used after the procedure, but the swelling and inflammation may affect the measurements. Therefore, this technology may play a role when performed before G-POEM to define who would benefit from pyloric intervention, but further studies are needed to validate its use.

Another risk factor of the response to the G-POEM procedure was also reported by Gonzalez et al. [25] and suggests that diabetes and female gender were associated with a poor response while idiopathic and postoperative etiologies were predictive of success. Diabetes is a complex disease that affects not only the stomach but also the small bowel, explaining why it leads to worse outcomes. When we compared these results with those using gastric electrical stimulation, which has demonstrated better outcomes in the diabetic population, with better glycemic control and lower hemoglobin A1c levels, as well as more consistent symptom improvement in the diabetic (vs. idiopathic) subgroup $[34,45]$, in the future, we may rely on a 
Table 5 Adverse events severity.

\begin{tabular}{|c|c|c|c|}
\hline Study & $\begin{array}{l}\text { Adverse events } \\
\text { (procedure- } \\
\text { related) }\end{array}$ & Adverse event (type) & Severity \\
\hline Rodriguez J. et al, 2018 & 10 & $\begin{array}{l}4 \text { bleeding } \\
1 \text { capnoperitoneum and subcutaneous emphysema (diagnostic laparoscopy) } \\
2 \text { severe dehydration } \\
3 \text { repeat upper endoscopy }\end{array}$ & $\begin{array}{l}\text { Moderate } \\
\text { Severe } \\
\text { Moderate } \\
\text { Moderate }\end{array}$ \\
\hline Landreneau et al, 2018 & 1 & 1 abdominal pain (needed diagnostic laparoscopy) & Severe \\
\hline Malik Z. et al, 2018 & 1 & 1 pulmonary embolism & Severe \\
\hline Gonzalez J.M. et al, 2017 & 9 & $\begin{array}{l}4 \text { pneumoperitoneum } \\
1 \text { pneumoperitoneum and abscess } \\
2 \text { bleeding } \\
1 \text { stricture (delayed) }\end{array}$ & $\begin{array}{l}\text { Mild } \\
\text { Severe } \\
\text { Moderate } \\
\text { Moderate }\end{array}$ \\
\hline Xue H.B. et al, 2017 & 0 & none & - \\
\hline $\begin{array}{l}\text { Mekaroonkamol P. et al, } \\
2019\end{array}$ & 3 & $\begin{array}{l}1 \text { tension capnoperitoneum } \\
1 \text { bleeding ulcer } \\
1 \text { exacerbation of pre existing chronic obstructive pulmonary disease }\end{array}$ & $\begin{array}{l}\text { Mild } \\
\text { Moderate } \\
\text { Moderate }\end{array}$ \\
\hline Hustak R. et al, 2018 & 1 & 1 bleeding ulcer & Moderate \\
\hline Dacha S. et al, 2017 & 1 & 1 tension pneumoperitoneum & Mild \\
\hline $\begin{array}{l}\text { Hernandez-Mondragon } \\
\text { O.V. et al, } 2017\end{array}$ & 4 & 4 abdominal pain & Mild \\
\hline Jacques J. et al, 2019 & 28 & $\begin{array}{l}\text { ( } 8 \text { not related to G-POEM) } \\
3 \text { gastric perforation } \\
1 \text { abdominal pain (needed reoperation) } \\
8 \text { procedural abdominal pain } \\
1 \text { epistaxis } \\
7 \text { Gl bleeding }\end{array}$ & $\begin{array}{l}\text { Mild } \\
\text { Severe } \\
\text { Mild } \\
\text { Mild } \\
\text { Moderate }\end{array}$ \\
\hline
\end{tabular}

personalized therapeutic approach depending on the etiology to lead to better outcomes. Further randomized studies are needed to be performed to confirm these results.

The post-procedure 4-hour gastric emptying scintigraphy was performed in all 10 studies, and there was significant variability in these improvement results. Hustak et al. [20] reported that GES was normalized in all patients (100\%), while Xue et al. [26] demonstrated a decrease in GES of $83 \%$. In the Gonzalez et al. [24] study, GES was normalized in $70 \%$ of cases. However, comparing the mean values before and after the intervention, a significant improvement was found in the mean half emptying time but not in the residual percentage at 4-hour GES. This discordance rate was $21 \%$, in favor of a clinical improvement despite disturbed GES, except for one case. Landreaneau et al. [1] compared G-POEM with laparoscopic pyloroplasty and showed no difference in this outcome between the two procedures ( $P=0.907)$; most patients showed improved GES after undergoing either G-POEM or laparoscopic pyloroplasty (85.7 vs. $83.3 \%$ ). However, normal gastric emptying does not seem to be necessary for a good symptomatic response, and, together with the $\mathrm{GSCl}$ score, are the only two parameters to measure clinical success in most studies; the improvement in GES (or both) after G-POEM was achieved, with high rates, as related above. Because there is no consensus regarding how to define the therapeutic success of gastroparesis treatment, Mekaroonkamol et al. [23] proposed that the clinical criteria to undergo the GPOEM procedure should be a baseline GCSI of at least 2.0 and a GES gastric retention rate greater than $20 \%$ at 4 hour.

Finally, to suggest that G-POEM is a safe procedure, gastrointestinal bleeding was the most common event (32\%), followed by abdominal pain (30\%) and pneumoperitoneum (24\%). Bleeding gastrointestinal cases were treated by endoscopy, while the abdominal pain treatment was considered severe in 4 cases $(4 / 11)$ and needed diagnostic laparoscopy [1, 19, 22, 25] ( $>$ Fig. 8). No related death occurred, except for the death of a patient in Rodriguez et al. study and one patient in Landreneau et al. study $[1,19]$. However, on autopsy, these deaths were determined to be related to underlying cardiac disease. Adverse events were classified according to Cotton et al [46] as mild, moderate, and severe as shown in $>$ Table 5.

\section{Limitations}

We conducted a comprehensive literature search and included all the available data in this regard. Our meta-analysis is weakened by limitations inherent to meta-analyses and the included studies. Furthermore, most of the data were derived from observational studies, with all of them being of very low-quality evidence. G-POEM is a novel technique with promising outcomes. However, we still cannot affirm for how long symptoms will remain improved, a situation likely to be explained, in part, 
by the short follow-up duration of the studies. The heterogeneity encountered in GCSI analysis was still high, even excluding the outlier study that presented a publication bias. However, all the studies showed a decrease in the values of GCSI and improved symptoms, indicating that the heterogeneity may be due to different population numbers $(n=7-100)$, baseline severity of the disease and follow-up periods ( $1 \mathrm{~m}-18 \mathrm{~m}$ ) across each study and not to the effects. GES heterogeneity was also high, and all the studies improved GES as well. Finally, there were other limitations in the present study including its retrospective design and that the experienced endoscopists performed most of the procedures.

\section{Conclusion}

G-POEM is effective, safe, minimally invasive and shows promising outcomes in the clinical response and gastric emptying studies. This procedure must be in the arsenal of treatment options for refractory gastroparesis; when performed by experienced hands, it shows a low risk of adverse events. However, there are only short- and mid-term efficacy studies; further controlled trials are needed to predict those who respond best to this treatment and to establish the long-term efficacy of this technique.

\section{Competing interests}

The authors declare that they have no conflict of interest.

References

[1] Landreneau JP, Strong AT, El-Hayek K et al. Laparoscopic pyloroplasty versus endoscopic per-oral pyloromyotomy for the treatment of gastroparesis. Surg Endosc 2019; 33: 773-781

[2] Parkman HP, Hasler WL et al. American Gastroenterological Association technical review on the diagnosis and treatment of gastroparesis. Gastroenterology 2004; 127: 1592-1622

[3] Camilleri M, Parkman HP, Shafi MA et al. Clinical guideline: management of gastroparesis. Am J Gastroenterol 2013; 108: 18-37;38

[4] Oh JH, Pasricha PJ. Recent advances in the pathophysiology and treatment of gastroparesis. J Neurogastroenterol Motil 2013; 19: $18-24$

[5] Xu J, Chen T, Elkholy S et al. Gastric peroral endoscopic myotomy (G-POEM) as a treatment for refractory gastroparesis: long-term outcomes. Can J Gastroenterol Hepatol 2018; 2018: 6409698

[6] Jones MP, Maganti K. A systematic review of surgical therapy for gastroparesis. Am J Gastroenterol 2003: 98; 2122-2129

[7] Arts ], Holvoet L, Caenepeel P et al. Clinical trial: a randomized-controlled crossover study of intrapyloric injection of botulinum toxin in gastroparesis. Aliment Pharmacol Ther 2007; 26: 1251-1258

[8] Friedenberg FK, Palit A, Parkman HP et al. Botulinum toxin A for the treatment of delayed gastric emptying. Am J Gastroenterol 2008; 103: $416-423$

[9] Ahuja NK, Clarke JO. Pyloric therapies for gastroparesis. Curr Treat Options Gastroenterol 2017; 15: 230-240

[10] Khashab MA, Besharati S, Ngamruengphong $S$ et al. Refractory gastroparesis can be successfully managed with endoscopic transpyloric stent placement and fixation (with video). Gastrointest Endosc 2015; 82: 1106-1109

[11] Clarke JO, Snape WJJ. Pyloric sphincter therapy: botulinum toxin, stents, and pyloromyotomy. Gastroenterol Clin North Am 2015; 44: 127-136

[12] Kawai M, Peretta S, Burckhardt O et al. Endoscopic pyloromyotomy: a new concept of minimally invasive surgery for pyloric stenosis. Endoscopy 2012; 44: 169-173

[13] Chaves DM, Gusmon CC, Mestieri LHM et al. A new technique for performing endoscopic pyloromyotomy by gastric submucosal tunnel dissection. Surg Laparosc Endosc Percutan Tech 2014; 24: 92-94

[14] Khashab MA, Stein E, Clarke JO et al. Gastric peroral endoscopic myotomy for refractory gastroparesis: first human endoscopic pyloromyotomy (with video). Gastrointest Endosc 2013; 78: 764-768

[15] Chaves DM, de Moura EGH, Mestieri LHM et al. Endoscopic pyloromyotomy via a gastric submucosal tunnel dissection for the treatment of gastroparesis after surgical vagal lesion. Gastrointest Endosc 2014; 80: 164

[16] Moher D, Shamseer L, Clarke M et al. Preferred reporting items for systematic review and meta-analysis protocols (PRISMA-P) 2015 statement. Syst Rev 2015; 4: 1

[17] Stroup DF, Berlin JA, Morton SC et al. Meta-analysis of observational studies in epidemiology: a proposal for reporting Meta-analysis Of Observational Studies in Epidemiology (MOOSE) group. JAMA 2000; 283: 2008-2012

[18] Guyatt GH, Oxman AD, Vist GE et al. GRADE: an emerging consensus on rating quality of evidence and strength of recommendations. BM] 2008; 336: 924-926

[19] Rodriguez J, Strong AT, Haskins IN et al. Per-oral pyloromyotomy (POP) for medically refractory gastroparesis: short term results from the first 100 patients at a high volume center. Ann Surg 2018; 268: 421-430

[20] Hustak R, Vackova Z, Rabeckova Z et al. Per-oral endoscopic pyloromyotomy (G-poem) in the treatment of refractory gastroparesis-midterm single centre experience. Gastrointest Endosc [Internet] 2018; 87: AB304-AB305

[21] Hernandez Mondragon OV, Palos Cuellar R, Blanco Velasco G et al. Gastric per-oral endoscopic pyloromyotomy (G-POEM) in the treatment of refractory gastroparesis: Experience of the first 9 cases in a Mexico United. Eur Gastroenterol ] [Internet] 2017; 5: A442

[22] Jacques J, Pagnon L, Hure F et al. Peroral endoscopic pyloromyotomy is efficacious and safe for refractory gastroparesis: prospective trial with assessment of pyloric function. Endoscopy 2019; 51: 40-49

[23] Mekaroonkamol P, Patel V, Shah R et al. Association between duration or etiology of gastroparesis and clinical response after gastric per-oral endoscopic pyloromyotomy. Gastrointest Endosc 2019; 5: 969-976

[24] Malik Z, Kataria R, Modayil R et al. Gastric per oral endoscopic myotomy (G-POEM) for the treatment of refractory gastroparesis: early experience. Dig Dis Sci 2018; 63: 2405-2412

[25] Gonzalez JM, Benezech A, Vitton V et al. G-POEM with antro-pyloromyotomy for the treatment of refractory gastroparesis: mid-term follow-up and factors predicting outcome. Aliment Pharmacol Ther 2017; 46: 364-370

[26] Xue HB, Fan HZ, Meng XM et al. Fluoroscopy-guided gastric peroral endoscopic pyloromyotomy (G-POEM): a more reliable and efficient method for treatment of refractory gastroparesis. Surg Endosc 2017; 31: 4617-4624

[27] Dacha S, Mekaroonkamol P, Li L et al. Outcomes and quality-of-life assessment after gastric per-oral endoscopic pyloromyotomy (with video). Gastrointest Endosc [Internet] 2017; 86: 282-289

[28] Dacha S, Mekaroonkamol P, Li L et al. Outcomes and quality-of-life assessment after gastric per-oral endoscopic pyloromyotomy (with video). Gastrointest Endosc 2017; 86: 282-289 
[29] Rao AS, Camilleri M. Review article: metoclopramide and tardive dyskinesia. Aliment Pharmacol Ther 2010; 31: 11-19

[30] Schey R, Saadi M, Midani D et al. Domperidone to treat symptoms of gastroparesis: benefits and side effects from a large single-center cohort. Dig Dis Sci 2016; 61: 3545-3451

[31] Khashab MA, Ngamruengphong S, Carr-Locke D et al. Gastric per-oral endoscopic myotomy for refractory gastroparesis: results from the first multicenter study on endoscopic pyloromyotomy (with video). Gastrointest Endosc 2017; 85: 123-128

[32] Zoll B, Zhao H, Edwards MA et al. Outcomes of surgical intervention for refractory gastroparesis: a systematic review. J Surg Res 2018; 231: $263-269$

[33] Lal N, Livemore S, Dunne D et al. Gastric electrical stimulation with the enterra system: a systematic review. Gastroenterol Res Pract 2015; 2015: 762972

[34] Abell T, McCallum R, Hocking M et al. Gastric electrical stimulation for medically refractory gastroparesis. Gastroenterology 2003; 125 : 421-428

[35] Bortolotti M. Gastric electrical stimulation for gastroparesis: a goal greatly pursued, but not yet attained. World J Gastroenterol 2011; 17 : 273-282

[36] Hibbard ML, Dunst CM, Swanstrom LL. Laparoscopic and endoscopic pyloroplasty for gastroparesis results in sustained symptom improvement. J Gastrointest Surg 2011; 15: 1513-1519

[37] Mekaroonkamol P, Shah R, Cai Q. Outcomes of per oral endoscopic pyloromyotomy in gastroparesis worldwide. World J Gastroenterol 2019; 25: 909-922
[38] Jones MP, Maganti K. A systematic review of surgical therapy for gastroparesis. Am J Clin Gastroenterol 2003; 98: 2122-2129

[39] Toro JP, Lytle NW, Patel AD et al. Efficacy of laparoscopic pyloroplasty for the treatment of gastroparesis. J Am Coll Surg 2014; 218: 652660

[40] Kahaleh M, Gonzalez J-M, Xu M-M et al. Gastric peroral endoscopic myotomy for the treatment of refractory gastroparesis: a multicenter international experience. Endoscopy 2018; 50: 10531058

[41] Lambdin JT, Zeddun S, Borum ML. Role of laparoscopic-assisted gastric per-oral endoscopic pyloromyotomy in refractory gastroparesis. Digest Dis Sci 2018; 63: 1366

[42] Shlomovitz E, Pescarus R, Cassera MA et al. Early human experience with per-oral endoscopic pyloromyotomy (POP). Surg Endosc 2015; 29: 543-551

[43] Allemang MT, Strong AT, Haskins IN et al. How I do it: per-oral pyloromyotomy (POP). J Gastrointest Surg 2017; 21: 1963-1968

[44] Cai MY, Xu JX, We-Zhebg Q et al. Gastric peroral endoscopic myotomy (G-POEM) as treatment for functional delayed gastric emptying: initial Asian experience. J Gastroenterol Hepatol [Internet] 2017; 32: 241-242

[45] McKenna D, Beverstein G, Reichelderfer M et al. Gastric electrical stimulation is an effective and safe treatment for medically refractory gastroparesis. Surgery 2008; 144: 564-566

[46] Cotton PB, Eisen GM, Aabakken L et al. A lexicon for endoscopic adverse events: report of an ASGE workshop. Gastrointest Endosc 2010; 71: $446-454$ 